Cell Research (2000), 10, 221-232

\title{
Nuclear apoptosis induced by isolated mitochondria
}

\author{
Jiang Zheng Fan, Yun Zhao, Xia Hong, Zhong He \\ ZHAI* \\ College of Life Sciences, Peking University, Beijing, 100871 \\ China
}

\begin{abstract}
We isolated and purified mitochondria from mouse livers and spinach leaves. When added into egg extracts of Xenopus laevis, they caused nuclei of mouse liver to undergo apoptotic changes. Chromatin condensation, margination and DNA ladder were observed. After incubating isolated mitochondria in some hypotonic solutions, and centrifuging these mixtures at high speed, we got mitochondrial supernatants. It was found that in the absence of cytosolic factor, the supernatant alone was able to induce apoptotic changes in nuclei. The effective components were partly of protein. DNA fragmentation was partly inhibited by caspase inhibitors AC-DEVD-CHO and ACYVAD-CHO. Meanwhile, caspase inhibitors fully blocked chromatin condensation. Primary characterization of the nuclear endonuclease(s) induced by mitochondrial supernatants was also conducted. It was found that this endonuclease is different from endonuclease $\mathrm{G}$, cytochrome c-induced nuclease, or $\mathrm{Ca}^{2+}$-activated endonuclease.
\end{abstract}

Key words: Mitochondria, supernatant, apoptosis, egg extract, nuclei, DNA cleavage.

\section{INTRODUCTION}

Apoptosis is a highly characterized form of cell death carried out by a genetically determined cell suicide program. It is induced by diverse stimuli and activated through a

\footnotetext{
* To whom correspondence should be addressed.

Fax: +86(10)6275-1850; E-mail: swzb@pku.edu.cn
} 
Nuclear apoptosis induced by isolated mitochondria

fairly complicated signal transduction pathway[1],[2]. Apoptosis ensures to eliminate harmful cells or extraneous cells[3]. It functions not only in sculpting shapes but also in optimizing functions. Defects in cell death will result in developmental abnormalities. Cell death also plays a key role in tissue turnover or at the end of an immune response in the adult animal. Balance between cell death and cell proliferation ensures a constant and controlled provision of fresh cells[4]. Failure in cell suicide regulation may cause neoplastic transformation[5],[6], autoimmune diseases or neurodegeneration in Alzheimer' s[7],[8] and Parkinson's disease[9],[10]. Cells undergoing apoptosis display distinctive morphological changes, including condensation of nuclei and cytoplasm, blebbing of cytoplasmic membranes, and fragmentation of the cell into apoptotic bodies that are rapidly phagocytosed by neighboring cells[11],[12]. The extensive degradation of chromosomal DNA into nucleosomal units as DNA ladder is a biochemical hallmark of apoptosis[11],[13].

Multiple lines of evidence strongly indicate that mitochondria play a role in the initiation of apoptosis[14-17]. In egg extracts of Xenopus laevis, a cytoplasmic fraction enriched in mitochondria was first found to be required in apoptosis[18]. In another cellfree system from cytosol of HeLa cells, cytochrome $\mathrm{c}$ was found to be crucial in activation of Apaf-1[19]. Alternations in mitochondrial permeability transition and subsequent dropping of mitochondrial membrane potential, altered cellular oxidation-reduction, and balance between pro- and antiapoptotic Bcl-2 family proteins are all the mitochondrial events implicated in apoptosis. The different signals that converge on mitochondria to initiate or block these events and their downstream effects reflect major pathways in physiological cell death[20],[21].

It is found that mitochondia lost its transmembrane potential before nuclear apoptotic changes occur. This specific pre-apoptotic collapse of membrane potential is detected in many cell types. It is mediated through permeability transition (PT) pores, a complicated proteinous megachannel that allows for the dissipation of inner membrane ion gradients. Significant data suggest that the PT is central to apoptotic processes[22]. PT will cause the release of caspases activators, cytochrome $\mathrm{c}$ or apoptosis inducing factor (AIF). Recent studies have demonstrated that Bcl-2 inhibits apoptosis by preventing release of cytochrome c from mitochondria[23,24]. Bax, a proapoptotic member of Bcl-2 family, triggers apoptosis by binding to PT pore causing the increase of mitochondrial membrane permeability and release of cytochrome $c[25]$. Whether there are any other factors existing in mitochondria that can introduce apoptosis in addition to cytochrome $\mathrm{c}$ is an open question. Just recently, Susin et al reported that the AIF was purified and sequenced [26,27].

In current studies, mitochondria were isolated and purified from mouse liver and spinach leaves. When added into egg extracts of Xenopus laevis, they caused nuclei of mouse liver to undergo apoptotic changes. Chromatin condensation, margination and DNA ladder were observed. By incubating isolated mitochondria in some hypotonic solutions, and centrifuging these mixtures at high speed, we got mitochondrial 
supernatants. We found that in the absence of cytosolic factor, the supernatant alone was able to elicit the apoptotic changes in nuclei. The effective components were partly of protein. DNA fragmentation was partly inhibited by caspase inhibitors AC-DEVD-CHO and AC-YVAD-CHO. Meanwhile, caspase inhibitors fully blocked chromatin condensation. Primary characterization of the nuclear endonuclease(s) induced by mitochondrial supernatants was also conducted. It was found that this endonuclease is different from endonuclease $\mathrm{G}$, cytochrome c-induced nuclease, or $\mathrm{Ca}^{2+}$-activated endonuclease.

\section{MATERIALS AND METHODS}

Xenopus eggs were collected, dejellied, rinsed with egg extract buffer (50 mM HEPES-KOH [pH 7.4], $50 \mathrm{mM} \mathrm{KCl}, 2 \mathrm{mM} \mathrm{MgCl}{ }_{2}, 2 \mathrm{mM} \beta$-Mercaptoethanol (MCE), when used for in vitro inducing nuclear apoptosis, MCE was removed) and lysed to prepare crude extract essentially as described with some modifications[28]. The crude extract was supplemented with aprotinin to $6 \mu \mathrm{g} / \mathrm{ml}$ and leupeptinin to $8 \mu \mathrm{g} / \mathrm{ml}$, and further separated into cytosol, membrane-rich, and gelatinous pellet fractions by ultracentrifugation at $200,000 \mathrm{~g}$ for $2 \mathrm{~h}$ in a HITACHI 55p-72 ultracentrifuge. The cytosol produced was stored under liquid nitrogen.

Sperm chromatin from Xenopus laevis was prepared as described[29].

Mouse liver nuclei were prepared as described[30]. In brief, minced mouse liver was homogenized in nuclear buffer (250 mM sucrose, $10 \mathrm{~m} \mathrm{M} \mathrm{Hepes,} \mathrm{pH} 7.4,15 \mathrm{~m} \mathrm{M} \mathrm{KCl,} 2 \mathrm{~m} \mathrm{M} \mathrm{MgCl}, 5 \mathrm{mM}$ EGTA, $0.5 \mathrm{mM}$ PMSF, $0.5 \mathrm{~m} \mathrm{M} \beta$-Mercaptoethanol, $2 \mathrm{mM}$ cytochalasin B). After filtration through a layer of silk-screen of 200 mesh, 2 volumes of homogenization buffer containing $2.3 \mathrm{M}$ sucrose was added and mixed thoroughly and centrifuged (RPS 50-2 rotor, $4{ }^{\circ} \mathrm{C}, 30 \mathrm{~min}, 124,000 \mathrm{~g}$ ) into a cushion consisting of homogenization buffer plus 2.3 M sucrose. The pellet was re-suspended in nuclei stock solution ( $10 \mathrm{~m} \mathrm{M}$ Pipes, $80 \mathrm{~m} \mathrm{M} \mathrm{KCl,} 20 \mathrm{mM} \mathrm{NaCl}, 250 \mathrm{mM}$ sucrose, $5 \mathrm{mM}$ EGTA, $0.5 \mathrm{~m}$ M Spermidine, $0.2 \mathrm{mM}$ Spermine, $50 \%$ glycerol) at a concentration of $5 \times 10^{4} \mathrm{nuclei} / \mathrm{ml}$ and stored under liquid nitrogen. Isolation and purification of mitochondria[31]. Livers from mouse were rinsed with ice-cold PBS, minced and homogenized in three volumes of H-buffer $(0.07 \mathrm{M}$ sucrose, $0.21 \mathrm{M}$ D-mannitol, $2 \mathrm{mM}$ Hepes, $0.05 \% \mathrm{BSA}-\mathrm{V}$ (W/V, defatted)). The homogenates were centrifuged at $1,100 \mathrm{~g}$ for $3 \mathrm{~min}$, while the supernatants were centrifuged at $6,780 \mathrm{~g}$ for $15 \mathrm{~min}$. Pellets were re-suspended in $1 / 4$ volume of H-buffer and centrifuged at 20,200 $\mathrm{g}$ for $15 \mathrm{~min}$. It was crude mitochondria. Re-suspended the crude mitochondria in $1 / 8$ volume of H-buffer, and centrifuged at 3,000 $\mathrm{g}$ for $3 \mathrm{~min}$, reserved the supernatant, re-suspended pellet, and centrifuged again. Combined two supernatants and centrifuged at 20,200 g for $20 \mathrm{~min}$. Discarded the upper fluffy pellet and added into $1 / 8$ volume of H-buffer, Mitochondria were collected by centrifugation. Re-suspended mitochondria in H-buffer, counted, and stored in liquid nitrogen.

Preparation of the mitochondrial supernatants ( $\mathrm{mt}$ supernatants). Purified mitochondria were incubated in $\mathrm{H}$-buffer, $4{ }^{\circ} \mathrm{C}, 2 \mathrm{~h}$, then centrifuged at $25,000 \mathrm{~g}$ for $15 \mathrm{~min}$. The supernatants were used to induce nuclear apoptosis in vitro.

The process of isolating mitochondria from spinach leaves was essentially the same as described[32].

Assay of in vitro apoptosis[33]. The reaction mixture contained $50 \mathrm{ml}$ of egg extracts buffer or egg extract S-200 and $\sim 1 \times 10^{5}$ mouse liver nuclei supplemented with isolated mitochondria or mitochondrial supernatants. They were incubated at $22{ }^{\circ} \mathrm{C}$ for indicated times. The in vitro apoptosis was monitored by placing $4 \mu \mathrm{l}$ aliquots of the samples on a microscope slide and mixed with $1 \mathrm{ml}$ of sample buffer containing $200 \mathrm{mM}$ sucrose, $30 \%$ formaldehyde, and $0.1 \mu \mathrm{g} / \mathrm{ml}$ DAPI. The nuclei were observed under a fluorescence microscope (Leica DMRB). After incubation, 10 volumes of buffer D (100 mM Tris-Cl [pH 8.0], $5 \mathrm{~m} \mathrm{M} \mathrm{EDTA,} 0.2 \mathrm{MNaCl}, 0.4 \%$ SDS, $0.2 \mathrm{mg} / \mathrm{ml}$ proteinase $\mathrm{K}$ ) was added to each reaction and incubated at $37^{\circ} \mathrm{C}$ overnight. The DNA was 
Nuclear apoptosis induced by isolated mitochondria

deproteinized with phenol and phenol-chloroform (1:1), precipitated with 2 volumes of ethanol. The DNA precipitate was re-suspended in $15 \mu \mathrm{l}$ TE $(\mathrm{pH} 8.0)$ with $1 \mu \mathrm{g} / \mu \mathrm{l}$ RNase. After incubation at $37^{\circ} \mathrm{C}$ for $2 \mathrm{~h}$, the DNA was loaded onto a $1.5 \%$ agarose gel, electrophoresed and visualized by staining with ethidium bromide and illumination with short-wave ultraviolet light.

\section{RESULTS}

Isolated mitochondria caused nuclei in egg extracts s-200 to undergo morphological changes characteristic of apoptosis

We isolated and purified mitochondria from mouse livers and from spinach leaves (Fig $1 \mathrm{~A})$, then put them into egg extracts s-200 with isolated nuclei. Under given concentrations, morphological changes characteristic of apoptosis occurred. Chromatin condensation, margination, and production of apoptotic bodies were observed clearly under the fluorescent microscope (Fig 1B). To confirm that the morphological changes in nuclei induced by isolated mitochondria reflected apoptosis, we examined then the cleavage of total chromosomal DNA. Within $4 \mathrm{~h}$ a typical DNA ladder occurred through gel electrophoresis. With increased concentration of mitochondria, the chromatin became progressively cleaved (Fig 1C). Our results indicated that not only the mitochondria from mouse but also those from spinach leaves had the ability to elicit the apoptosis in nuclei (Fig 1D).

Several kinds of divalent cations were used to examine the effects of purified mouse liver cells mitochondria on DNA cleavage during apoptosis. As Fig 1E showed, DNA degradation was dependent heavily on $\mathrm{Mg}^{2+}$ and $\mathrm{Ca}^{2+}$, and was inhibited partially by $\mathrm{Zn}^{2+}$. $\mathrm{Mn}^{2+}$ promoted DNA fragmentation extensively. The inhibitory effect of $\mathrm{Mn}^{2+}$ on DNA cleavage here was obviously different from that in cytochrome c-induced apoptosis, in which $\mathrm{Mn}^{2+}$ had an inhibitory effect. The finding that $\mathrm{Zn}^{2+}$ is inhibitory to the nuclease activity is consistent with the widely recognized effect of this divalent cation on the endogenous endonuclease responsible for apoptotic cleavage of DNA in animal systems [34].

\section{Mitochondrial supernatants caused apoptotic changes independently in isolated nuclei}

Mitochondrial supernatants ( $\mathrm{mt}$ supernatants) were prepared by incubating isolated mitochondria in egg extract buffer (E/M) or egg extract s-200 (S/M), and were found to be able to induced DNA fragmentation in nuclei (Fig 2A, lanes 2, 3, 5, 6; Fig 2B lane 4); supernatants prepared from nuclear buffer $(\mathrm{N} / \mathrm{M})$ or $\mathrm{H}$-medium $(\mathrm{H} / \mathrm{M})$ were not able to induced DNA fragmentation (Fig 2B lanes 5, 6), suggesting that the effective factors were released from mitochondria through the hypotonic shock. There was a high concentration of sucrose or mannitol in NB and $\mathrm{H}$-medium, which protected mitochondria from hypotonic shock. If $\mathrm{mt}$ supernatants were incubated directly with nuclei in extract buffer, apoptotic changes also occurred in nuclei. E/M caused nuclei to undergo apoptotic changes independent of cytosolic factors from egg extracts (Fig 2A lane 5).

It has been reported that there is an endonuclease in mitochondria that cleave ssDNA 


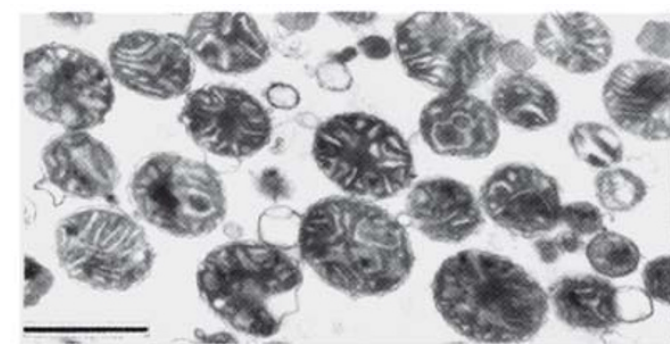

A

A Electron micrograph of isolated and purified mitochondria from mouse liver cells. Bar $=1 \mu \mathrm{m}$ B Apoptotic morphological changes in mouse liver nuclei incubated in Xenopus egg extract s200 with isolated mitochondria from mouse livers. About 100, 000 nuclei were added to $50 \mu \mathrm{l}$ $\mathrm{s}-200$ with mitochondria at final concentration of
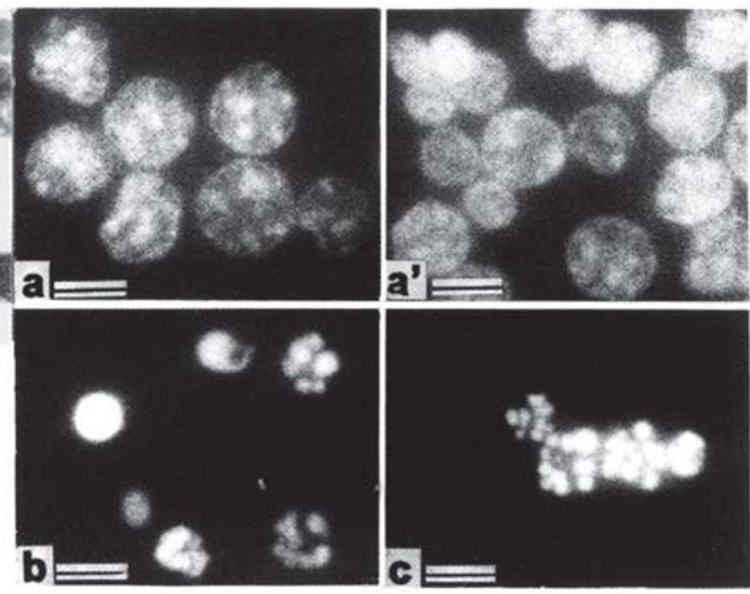

B

$2.4 \times 10^{7} / \mu 1$. Aliquots of nuclei were removed at different times, dyed with DAPI and examined by fluorescence microscopy. (a), $0 \mathrm{~min}$; (b), 1 h; (c), 2 h; (a'), Nuclei incubated in s-200 for 4 h. Bar=10 $\mu \mathrm{m}$.

C Mitochondria from mouse liver cells were isolated and purified,

\section{$\begin{array}{llllllll}1 & 2 & 3 & 4 & 5 & 6 & 7 & 8\end{array}$}

C

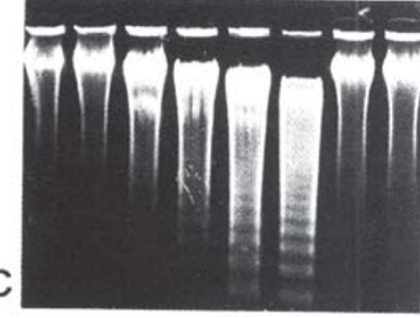

then added into 50 ( $1 \mathrm{~s}-200$ with final concentrations of $1,8 \times 10^{6}$

(l; $2,1.2 \times 107 \mu \mathrm{l} ; 3,1.6 \times 107 / \mu \mathrm{l} ; 4,2 \times 107 / \mu \mathrm{l} ; 5,2.4 \times 107 / \mu \mathrm{l} ; 6,2$.

$8 \times 107 / \mu \mathrm{l}$, or $1.6 \times 107 / \mu \mathrm{l}$ mitochondria in $50 \mathrm{ml} \mathrm{s}-200$ with $7,2 \mathrm{~m}$ $\mathrm{M}$ dATP; $8,4 \mathrm{~m} \mathrm{M}$ dATP. $22{ }^{\circ} \mathrm{C}$ incubated for $4 \mathrm{~h}$, and chromatin DNA was analyzed. In $50 \mathrm{ml} \mathrm{s}-200$, when dATP was introduced into with $1.6 \times 10^{7} / \mathrm{ml}$ mitochondria, apoptosis could not be induced. It demonstrates that mitochondria are able to induce apoptotic DNA fragmentation while dATP does not play a role in this process in $\mathrm{s}-200$.

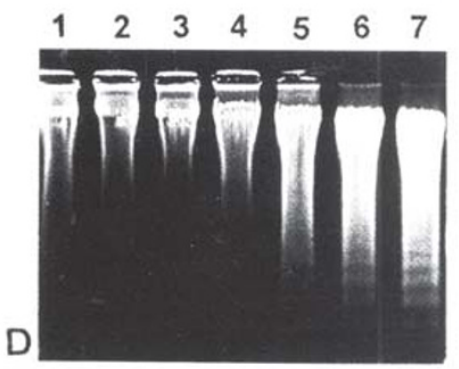

D Mitochondria from spinach mesophyllic cells were purified, added into $50 \mu \mathrm{l} \mathrm{s}-200$ with final concentrations of 1,$0 ; 2,0.48 \times$ $10^{6} / \mu \mathrm{l} ; 3,1.6 \times 10^{6} / \mu \mathrm{l} ; 4,3.2 \times 10^{6} / \mu \mathrm{l} ; 5,6.4 \times 10^{6} / \mu \mathrm{l} ; 6,9 \times 10^{6} / \mu \mathrm{l} ; 7$, $1.28 \times 10^{7} / \mu 1.22^{\circ} \mathrm{C}$ incubated for $4 \mathrm{~h}$, and chromatin DNA was analyzed. It demonstrates that mitochondria from plant cells are also able to induce apoptotic DNA fragmentation.

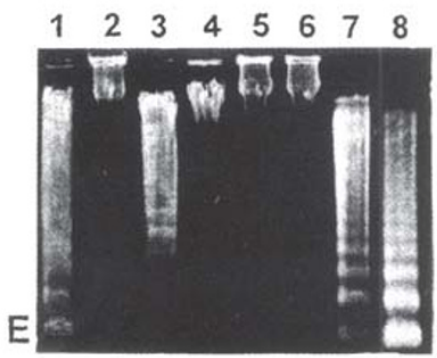

E Effects of different divalent cations on DNA fragmentation induced by isolated mouse liver mitochondria. Nuclei were incubated in egg extracts s-200 with $1.2 \mathrm{~m} 108 / \mathrm{ml}$ mitochondria plus 1 , $5 \mathrm{~m} \mathrm{M} \mathrm{Mg}^{2+}$; 2, $5 \mathrm{~m} \mathrm{M} \mathrm{EDTA;} \mathrm{3,} 2 \mathrm{~m} \mathrm{M} \mathrm{Zn}^{2+}$; 4, $5 \mathrm{~m} \mathrm{M} \mathrm{Zn}^{2+}$; 5, $5 \mathrm{~m}$ M EGTA; 6, $5 \mathrm{~m} \mathrm{M} \mathrm{Ca}^{2+}$ plus $5 \mathrm{~m}$ M EDTA; 7, $5 \mathrm{~m} \mathrm{M} \mathrm{Mn}^{2+}$; 8, 10 $\mathrm{m} \mathrm{M} \mathrm{Mn}{ }^{2+}$

Fig 1. Nuclear apoptosis induced by mitochondria from mouse or spinach cells 
Nuclear apoptosis induced by isolated mitochondria

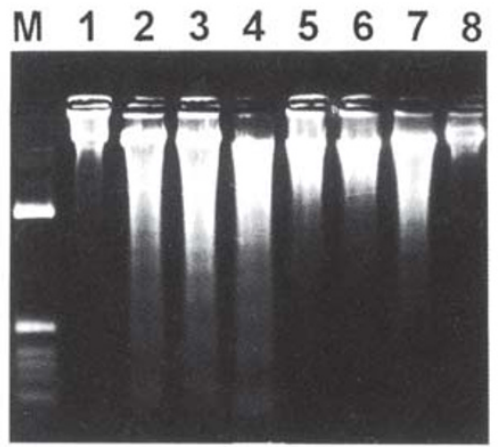

A

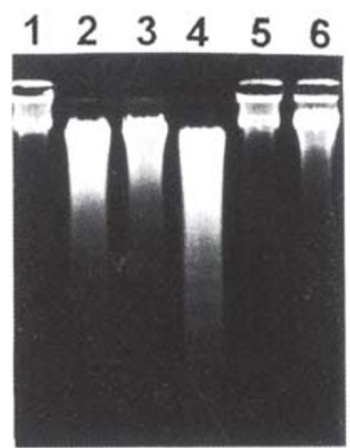

B

Fig 2. DNA fragmentation induced in different reaction systems.

A: Isolated mitochondria were incubated in egg extract buffer (E/M) or egg extracts s-200 (S/M) with the concentration of $6 \times 10^{8} / \mathrm{ml}$ for $2 \mathrm{~h}$, centrifuged $25,000 \mathrm{~g}$ for $15 \mathrm{~min}$, the supernatant from $\mathrm{E} / \mathrm{M}$ or S/M was used to induce DNA fragmentation. Then, nuclei were incubated in 1, extract buffer only, or in extract buffer with $2,10 \mu \mathrm{l}$ supernatant from $\mathrm{E} / \mathrm{M} ; 3,10 \mu \mathrm{l}$ supernatant from $\mathrm{S} / \mathrm{M}$; or with $4,1.2 \times 10^{8} / \mathrm{ml}$ mitochondria were introduced into extract as positive control. At the same time, the nuclei were incubated in s-200 with $5,10 \mu \mathrm{l}$ supernatant from $\mathrm{E} / \mathrm{M} ; 6,10 \mu \mathrm{l}$ supernatant from $\mathrm{S} / \mathrm{M}$; $7,1.2 \times 10^{8} / \mathrm{ml}$ mitochondria or in $8, \mathrm{~s}-200$ only.

B: Reactions were carried out as described in A. Mitochondria were incubated in buffer $\mathrm{H}(\mathrm{H} / \mathrm{M})$, or in nuclear preparation buffer $(\mathrm{N} / \mathrm{M})$. In this reaction, mitochondria were used as re-suspended in buffer $\mathrm{H}$ after incubated in nuclear buffer (N/M) for $2 \mathrm{~h}$ (as $\mathrm{M} / \mathrm{N} / \mathrm{M}$ ). Nuclei were incubated in 1 , egg extract buffer; or in extract buffer with $2,1.2 \times 10^{8} / \mathrm{ml}$ re-suspended mitochondria $(\mathrm{M} / \mathrm{N} / \mathrm{M}) ; 3$, $10 \mu$ buffer $\mathrm{H} ; 4,10 \mu \mathrm{l}$ supernatant from $\mathrm{E} / \mathrm{M} ; 5,10 \mathrm{~m}$ supernatant from $\mathrm{H} / \mathrm{M}$; or $6,10 \mu \mathrm{l}$ supernatant from N/M. It shows that some factor(s) released from mitochondria cause DNA fragmentation in purified nuclei and it is independent of cytoplasmic factors. The release may be conducted in a hypotonic solution. M, Marker, pBR322/Hinf I.

$\begin{array}{llllllll}1 & 2 & 3 & 4 & 5 & 6 & 7 & M\end{array}$

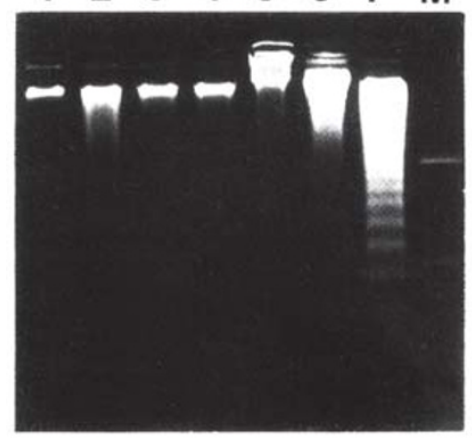

Fig 3. Mitochondria factors responsible for the activation of DNA fragmentation is localized in the nuclei. Reactions were carried out as described in Fig 2. In lanes 1 to 4, sperm chromatin from Xenopus laevis was incubated in egg extract buffer. 1, sperm chromatin only; and sperm chromatin with $2,1.2 \mu 10^{8} / \mathrm{ml}$ mitochondria; 3 , sperm chromatin with $10 \mu \mathrm{l} \mathrm{E/M;} 4$, or with $10 \mu \mathrm{l} \mathrm{S} / \mathrm{M}$. In lanes 5 to 7 , mouse liver nuclei were incubated in extract buffer to substitute sperm. 5, nuclei only; and nuclei with $6,10 \mu \mathrm{l} \mathrm{S/M}$; or with 7, $10 \mu \mathrm{l} \mathrm{E} / \mathrm{M}$. The result shows that it is the nuclease in nuclei that are activated by factors from mitochondria and causes DNA fragmentation. M, Marker, pBR322/Hinf I.

and dsDNA[35]. We examined if this endonulease functioned in mt supernatants. Demembraned sperms of Xenopus laevis or mouse liver nuclei were treated with $\mathrm{mt}$ supernatants. After $4 \mathrm{~h}$ incubation, nuclear DNA was analyzed. It showed that there was no nuclease activity in $\mathrm{mt}$ supernatants (Fig $3 \mathrm{~A}$ lanes 3,4 ), but there was some factor(s) 
Jiang ZF et al.

that could activate the endonuclease in nuclei (Fig 3A lanes 6, 7). Sperm chromatin incubated with mitochondria was degraded slightly (Fig 3A lane 2). The inducing activity of DNA fragmentation in E/M was higher than that in $\mathrm{S} / \mathrm{M}$. These results demonstrated that the activated endonuclease(s) responsible for the DNA fragmentation was located in nuclei.

The nature of effective factors in mitochondrial supernatants was partly of protein

When mt supernatants were treated with proteinase $\mathrm{K}\left(100 \mu \mathrm{g} / \mathrm{ml}, 10 \mathrm{~min}\right.$ at $\left.37^{\circ} \mathrm{C}\right)$ and inactivated with $1 \mathrm{~m} \mathrm{M} \mathrm{PMSF}$, its inducing activity of DNA cleavage lost partly (Fig 4A lane 3). Since there was no protein detected by a SDS-PAGE electrophoresis of $\mathrm{mt}$
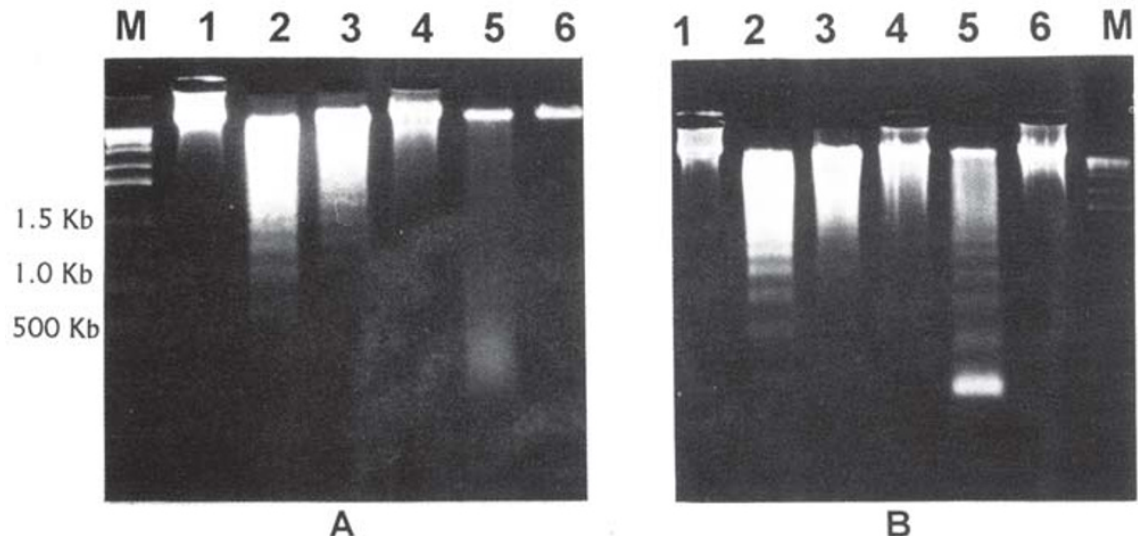

B

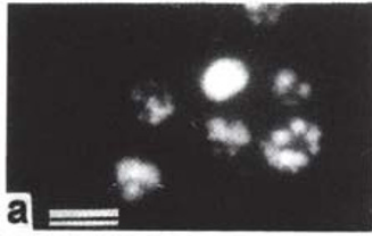

Fig 4. The factors causing DNA fragmentation was not only a protein and DNA fragmentation was partially inhibited by the caspase inhibitors.

A: Mouse liver nuclei were incubated in 1, egg extract buffer only, or in extract buffer with 2, $10 \mu \mathrm{l}$ supernatant from $\mathrm{E} / \mathrm{M}$; with $3,10 \mu \mathrm{l} \mathrm{E} /$

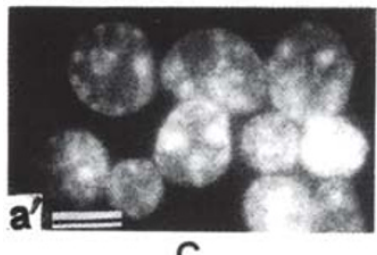
$\mathrm{M} / \mathrm{PK} / \mathrm{PMSF}$ (supernatant from $\mathrm{E} / \mathrm{M}$ were treated with $0.1 \mathrm{mg} / \mathrm{mL}$ proteinase $\mathrm{K}, 37^{\circ} \mathrm{C}, 10 \mathrm{~min}$, and stopped by adding PMSF to a final concentration of $0.2 \mathrm{mM}$ ); with $4,10 \mu \mathrm{l} \mathrm{E/PK/PMSF}$ (egg extract buffer was treated by proteinase $\mathrm{K}$ and PMSF); with $5,10 \mu \mathrm{l} \mathrm{E} / \mathrm{PK}$ (extract buffer was treated by proteinase K); or with 6, 10 $\mu$ l E/PMSF (extract buffer was treated by PMSF).

B: Nuclei were incubated in 1, extract buffer, or extract buffer with 2, $10 \mu \mathrm{l}$ supernatant from $\mathrm{E} / \mathrm{M}$; or with $3,10 \mu \mathrm{l}$ supernatant from $\mathrm{E} / \mathrm{M}$ plus $0.1 \mathrm{mM}$ YVAD and $10 \mathrm{~m} \mathrm{M}$ DEVD. At the same time, nuclei were incubated in 4, egg extracts S-200; or in egg extracts S-200 with 5, $1 \mathrm{mM}$ cytochrome c; or with $6,1 \mu \mathrm{M}$ cytochrome c plus $0.1 \mathrm{mM}$ YVAD and $10 \mu \mathrm{M}$ DEVD. M, $1 \mathrm{~kb}$ marker.

C: The nuclear condensation could be induced when mouse liver nuclei were incubated in extract buffer with $\mathrm{mt}$ supernatants $(\mathrm{Ca})$. However, caspase (0.1 mM YVAD and 10mM DEVD) inhibitor entirely blocked nuclear condensation ( $\mathrm{Ca}$ '). 
Nuclear apoptosis induced by isolated mitochondria

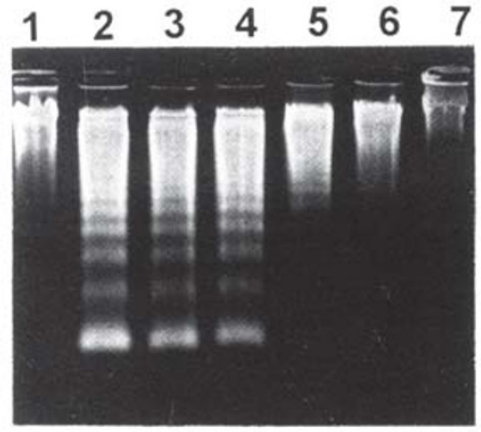

$\mathrm{Aa}^{\prime}$

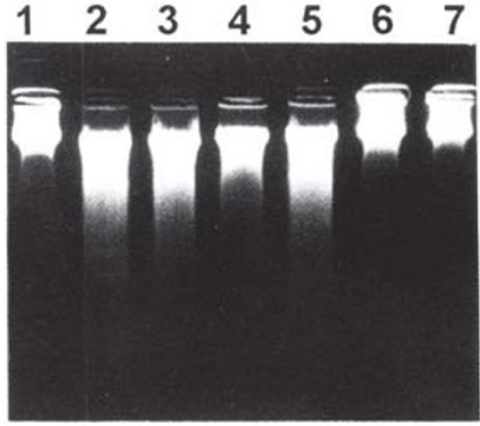

$A b^{\prime}$

A The sensitivities of the nucleases to $\mathrm{KCl}$. Aa': Sensitivities of nuclease activated by cytochrome c in egg extracts S-200. Mouse liver nuclei were incubated in 1, s-200; or 2, in s-200 with $1 \mu \mathrm{M}$ cytochrome c; plus 3, $20 \mathrm{~m} \mathrm{M}$; 4, $40 \mathrm{mM}$; , $60 \mathrm{mM} ; 6,80 \mathrm{mM}$; 7, $100 \mathrm{mM} \mathrm{KCl}$. Ab’: Sensitivities of nuclease activated by E/ $\mathrm{M}$ in nuclei. Nuclei were incubated in 1, egg extract buffer or in extract buffer with 2, 10 (1 E/M; plus 3, 10 $\mathrm{m} \mathrm{M} ; 4,20 \mathrm{~m} \mathrm{M} ; 5,40 \mathrm{~m} \mathrm{M} ; 6,60 \mathrm{~m} \mathrm{M} ; 7,80 \mathrm{~m} \mathrm{M} \mathrm{KCl}$. It demonstrates that there is some difference between two nucleases on sensitivity to $\mathrm{KCl}$.

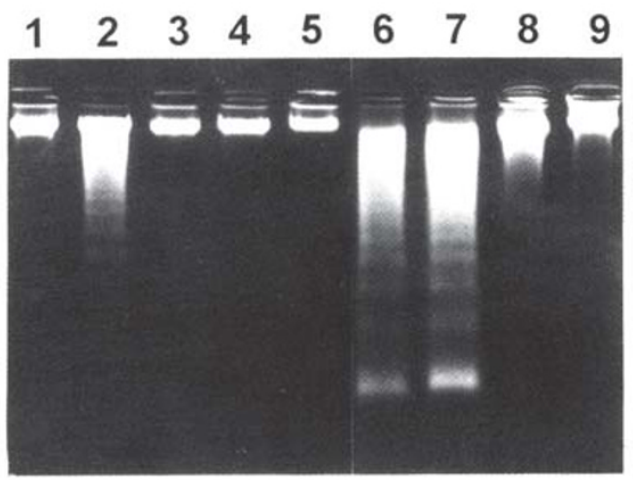

B

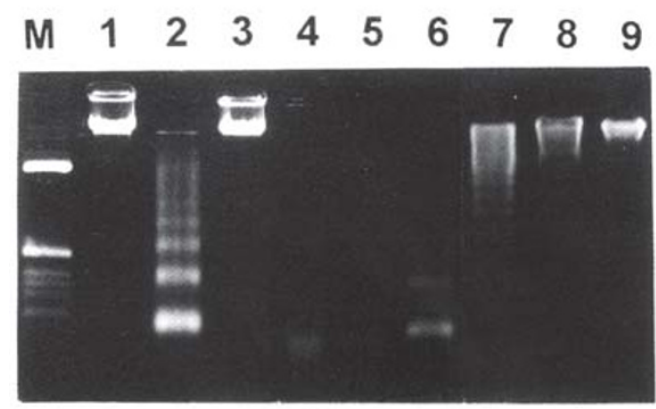

C
B The sensitivities of the nucleases to $\mathrm{N}$ ethylmaleimide (NEM). Mouse liver nuclei were incubated in 1 , extract buffer or 2, extract buffer with $10 \mu \mathrm{l} \mathrm{E/M;} \mathrm{and} \mathrm{extract} \mathrm{buffer} \mathrm{with} 10 \mu \mathrm{l} \mathrm{E/M}$ plus 3, 0 . 3 m M NEM; 4, $1 \mu \mathrm{M}$ NEM; 5 , 3 m M NEM; or nuclei were incubated in 6, extracts $\mathrm{S}-200$ with $1 \mu \mathrm{M}$ cytochrome c; and plus 7, 0.3 m M NEM; 8, 3 m M NEM; or 9 , only mouse liver nuclei in s-200. It demonstrates that the nuclease activated by the factors in mitochondria is more sensitive to NEM than that activated by cytochrome c.

C Effects of different divalent cations and Nethylmaleimide (NEM) on DNA fragmentation induced by $\mathrm{Ca}^{2+}$. Mouse liver nuclei were incubated in 1 , egg extract buffer or 2, extract buffer with $6 \mathrm{~m} \mathrm{M} \mathrm{Ca}^{2+}$; plus 3, $5 \mathrm{~m} \mathrm{M} \mathrm{Zn}^{2+}$; 4, $5 \mathrm{~m} \mathrm{M} \mathrm{Mn}^{2+}$; 5, $10 \mathrm{~m} \mathrm{M} \mathrm{Mn}^{2+}$; or 6, $0.1 \mathrm{~m} \mathrm{M}$ YVAD and $10 \mathrm{~m} \mathrm{M}$ DEVD; or 7, $0.3 \mathrm{~m} \mathrm{M}$ NEM; 8, 1 m M NEM; or 9, 3 m M NEM. It demonstrates that the activity of the endonuclease activated by $\mathrm{Ca}^{2+}$ is enhanced greatly by $\mathrm{Mn}^{2+}$ (the chromatin DNA was digested so strongly that only part of 200 bp DNA could be seen. Lane 4, 5), inhibited by $\mathrm{Zn}^{2+}$ and partially inhibited by $0.3 \mathrm{~m} \mathrm{M}$ or $1 \mathrm{~m} \mathrm{M} \mathrm{NEM.} \mathrm{M,}$ Marker, pBR322/Hinf I.

Fig 5.Primary characterization of the nuclear endonuclease induced by mitochondrial supernatants 
supernatants stained with Coomassie Brilliant Blue, we considered that other factor(s) maybe responsible for DNA fragmentation existed in the supernatants. Next, the inhibitory effect of caspase inhibitors on mt supernatant-induced DNA fragmentation was investigated, and we found that while AC-DEVD-CHO and AC-YVAD-CHO fully inhibited cytochrome c-induced DNA degradation, they onlye partially inhibited mt supernatantinduced DNA fragmentation even with the same concentrations (Fig 4B lane 3). However, caspase inhibitor entirely blocked nuclear condensation induced by supernatants (Fig $4 \mathrm{C})$. These results strongly suggested that there is more than one factor functioning in mt supernatants.

\section{Primary characterization of the nuclear endonuclease induced by mito- chondrial supernatants}

First, sensitivities of different endonucleases to $\mathrm{KCl}$ were investigated. Fig $5 \mathrm{~A}$ showed that the nuclease activated by cytochrome $\mathrm{c}$ was fully inhibited by $\mathrm{KCl}$ at a concentration of $80 \mathrm{~m} \mathrm{M}$, compared with $60 \mathrm{~m} \mathrm{M}$ for mt supernant-activated one.

Then sensitivities to N-ethylmaleimide (NEM) were examined. NEM is a sort of sulfhydryl inhibitor. Fig 5B showed that for cytochrome c-induced endonuclease, $3 \mathrm{~m} \mathrm{M}$ NEM gave full inhibition; for the mt supernatant- activated nuclease, NEM concentration for full inhibition was $0.3 \mathrm{~m} \mathrm{M}$, indicating that the sensitivity of $\mathrm{mt}$ superntantinduced nuclease to NEM was obviously higher than that of cytochrome c-induced nuclease.

Effects of caspase inhibitors or NEM on $\mathrm{Ca}^{2+}$-activated nuclear endonuclease were also investigated. Fig $5 \mathrm{C}$ demonstrated that caspase inhibitors had no effect on the nuclease. The NEM concentration required for full inhibition of this nuclease was $1 \mathrm{~m} \mathrm{M}$.

\section{DISCUSSION}

In the modulation of apoptosis in vertebrate cells, mitochondria now are believed to play a central role[17],[21], [36]. Cytochrome $\mathrm{c}$ is liberated from mitochondria, and binds to Apaf-1 in cytosol[19],[37]. This binding which also needs dATP or ATP's co-operation alters the transformation of Apaf-1. Apaf-1 recruits procaspase-9 that will activates themselves in a high concentration. Activated caspase- 9 in turn cleaves procaspase- 3 and activates it. In this way, apoptosis is triggered irreversibly[16]. Bcl-2 family, for example, $\operatorname{Bax}[25], \mathrm{Bid}[38],[39]$ and Bcl-2[23], [24], controls apoptosis by mediating cytochrome c release from mitochondria in response to various stimuli[15]. There are AIF[26], [27] and precaspases such as precaspase-3[40] located in mitochondria, the function of latter in mitochondria is not clear.

Our finding that mitochondria from spinach leaves triggered apoptotic changes in isolated nuclei suggests that the role of mitochondria in apoptosis is conserved and common in cells. Although there is no verified proof demonstrating that mitochondria also plays a role in plant cell apoptosis, cytochrome $\mathrm{c}$ has been found to be able to induce nuclear apoptosis in cytosol prepared from plant cells[41]. 
Nuclear apoptosis induced by isolated mitochondria

The activity of DNA fragmentation was partially blocked by caspase inhibitors, suggesting that 1) a different endonuclease is functioning in our system or/and 2) more than one type of endonuclease was activated. The cation preference indicates that there is obvious difference between $\mathrm{mt}$ supernatant- activated and cytochrome c-activated nucleases. Mt supernatant-activated endonuclease(s) is dependent on the existence of $\mathrm{Ca}^{2+}$ and $\mathrm{Mg}^{2+} . \mathrm{Mn}^{2+}$ promotes its activity significantly. This $\mathrm{Mn}^{2+}$ preference strongly suggests that $\mathrm{mt}$ supernatant-activated endonuclease(s) may be endonuclease $\mathrm{G}$ which was found in mammalian nuclei[42],[43]. However, compared with the sensitivities of endonuclease $\mathrm{G}$ to $\mathrm{KCl}$ ( $40 \mathrm{~m} \mathrm{M}$ gives $90 \%$ inhibition) and to NEM ( $3 \mathrm{mM}$ gives to $90 \%$ inhibition), $\mathrm{mt}$ supernatant-activated nuclease(s) is much more sensitive to NEM $(0.3 \mathrm{~m}$ M gives $100 \%$ inhibition) and less sensitive to $\mathrm{KCl}$ ( $60 \mathrm{mM}$ gives $100 \%$ inhibition). There has been no research indicating that endonuclease $\mathrm{G}$ has the ability to cleave chromosomal DNA into nucleosomal fragments. So we considered that $\mathrm{mt}$ supernatant-induced nuclease(s) was not endonuclease G. It is also found that this endonuclease(s) is either different from cytochrome c-induced nuclease of which the sensitivity to NEM is more than $0.3 \mathrm{mM}$, or different from $\mathrm{Ca}^{2+}$-activated nuclease which requires more than $1 \mathrm{~m} \mathrm{M}$ NEM to fully inhibit its activity. Combining with all the results, it suggested that at least from the point of NEM sensitivity those three endonucleases are not likely to take part in $\mathrm{mt}$ supernatant-induced DNA cleavage, since the sensitivity of each to NEM is more than $1 \mathrm{~m} \mathrm{M}$. However, from the cation preference, $\mathrm{mt}$ supernant-activated nuclease is highly similar to $\mathrm{Ca}^{2+}$-activated nuclease. This similarity needs further studies. Since the concentration of $\mathrm{Ca}^{2+}$ in mitochondria is high, the function of $\mathrm{Ca}^{2+}$ release in response to some death signal may be also important. $\mathrm{Ca}^{2+}$ release will in turn accelerate the dissembly of nuclear chromatin. At present, we do not know the physiological functions of this endonuclease in nuclei and whether it participates in the process of DNA fragmentation during apoptosis in vivo. There is more than one type of effective factors released from mitochondria through hypotonic shock. One factor is of protein, the others are not. Although AC-DEVD- CHO and AC-YVAD-CHO were not able to fully inhibit DNA cleavage, they inhibited chromatin condensation elicited by $\mathrm{mt}$ supernatants at the same concentration. It suggests that the activity for nuclear fragmentation is dependent on caspases. It has been found that there are some precaspases in mitochondria, pro-caspase$3[40]$, and in nuclei, pro-caspase-1[44]. Activation of any caspase will undoubtedly cause chromatin condensation. Recently, AIF has been identified and cloned. This flavoprotein is reported to be sufficient to induce apoptosis of isolated nuclei. It causes chromatin condensation, large-scale cleavage of DNA and induces mitochondria to release cytochrome $\mathrm{c}$ and caspase-9. However, none of these effects is prevented by caspase inhibitor [27]. This is different from our observation that chromatin condensation was blocked by caspase inhibitors. We concluded that the effective factors in mt supernatants responsible for all the nuclear events are intricate, and the effects are combined. The detailed molecular basis is waiting for further studies. 
Jiang ZF et al.

\section{ACKNOWLEDGMENT}

Project was supported by the National Natural Science Fundation of China (Grant No. 39800075 and 19890380) and the special Funds for Major State Basic Research of China (Grant No. G19990539).

\section{REFERENCES}

[1] Kerr JF, Wyllie AH, Currie AR. Apoptosis: a basic biological phenomenon with wide-ranging implications in tissue kinetics. Br J Cancer 1972; 26:239-57.

[2] Reed JC. Bcl-2 and the regulation of programmed cell death. J Cell Biol 1994; 124:1-6.

[3] Tomei LD, Cope FO, eds. Apoptosis: The molecular basis of cell death. Current Communications in Cell and Molecular Biology. 1991. NY: Cold Spring Harbor Laboratory Press).

[4] Golstein P. Cell death in us and others. Science 1998; 281:1283.

[5] Tsujimoto Y, Cossman J, Jaffe E, et al. Involvement of the bcl-2 gene in human follicular lymphoma. Science 1985; 228:1440-3.

[6] Hockenbery DM, Oltvai ZN, Yin XM, et al. Bcl-2 functions in an antioxidant pathway to prevent apoptosis. Cell 1993; 75:241-51.

[7] Barinaga M. Is Apoptosis Key in Alzheimer's Disease? Science 1998; 281:1303-4.

[8] George P, Akihiko N, Paul L, et al. Apoptosis and Alzhermer' s disease. Science 1998; 282:1265.

[9] Schapira AH. Mitochondrial involvement in Parkinson' s disease, Huntington' s disease, hereditary spastic paraplegia and Friedreich's ataxia. Biochem Biophys Acta 1999; 1410(2):159-70.

[10] Merad-Boudia M, Nicole A, Santiard-Baron D, et al. Mitochondrial impairment as an early event in the process of apoptosis induced by glutathione depletion in neuronal cells: relevance to Parkinson's disease. Biochem Pharmacol 1998; 56:645-55.

[11] Wyllie AH, Kerr JF, Currie AR. Cell death: the significance of apoptosis. Int. Rev. Cyto. 1980; 68:251305.

[12] Kerr JF, Searle J, Harmon BV, et al. Perspectives in mammalian cell death. Potten, C. S. editor. Oxford University Press, Oxford. 1997; pg.93.

[13] Compton MM. A biochemical hallmark of apoptosis: internucleosomal degradation of the genome. Cancer Metastasis Rev 1992; 11:105-19.

[14] Kromer G, Zamzami N, Susin SA. Mitochondrial control of apoptosis. Immunol Today 1997; 44:4451.

[15] Reed JC. Double identity for proteins of the Bcl-2 family. Nature 1997; 387:773-5.

[16] Vaux DL. CED-4--the third horseman of apoptosis [comment]. Cell 1997; 90:389-90.

[17] Skulachev VP. Cytochrome $\mathrm{c}$ in the apoptotic and antioxidant cascades. Febs Lett 1998; 423:275-80.

[18] Newmeyer DD, Farschon DM, Reed JC. Cell-free apoptosis in Xenopus egg extracts: inhibition by Bcl2 and requirement for an organelle fraction enriched in mitochondria. Cell 1994; 79:353-64.

[19] Liu XS, Kim CN, Yang J, et al. Induction of apoptotic program in cell-free extracts: requirement for dATP and cytochrome c. Cell 1996; 86:147-57.

[20] Petit PX, Lecoeur H, Zom E, et al. Alterations in mitochondrial structure and function are early events of dexamethasone-induced thymocyte apoptosis. J Cell Biol 1995; 130:157-67.

[21] Green DR, Reed JC. Mitochondria and apoptosis Science 1998; 281:1309-12.

[22] Zamzami N, Susin SA, Marchetti P, et al. Mitochondrial control of nuclear apoptosis. J Exp Med 1996; 183:1533-44.

[23] Yang J, Liu X, Bhalla K, et al. Prevention of apoptosis by Bcl-2: release of cytochrome c from mitochondria blocked. Science 1997; 275:1129-32.

[24] Kluck RM, Bossy-Wetzel E, Green DR, et al. The release of cytochrome c from mitochondria: a primary 
Nuclear apoptosis induced by isolated mitochondria

site for Bcl-2 regulation of apoptosis. Science 1997; 275:1132-6.

[25] Marzo I, Brenner C, Zamzami N, et al. Bax and adenine nucleotide translocator cooperate in the mitochondrial control of apoptosis. Science 1998; 281:2027-31.

[26] Susin SA, Zamzami N, Castedo M, et al. Bcl-2 inhibits the mitochondrial release of an apoptogenic protease. J Exp Med 1996; 184:1331-41.

[27] Susin SA, Lorenzo HK, Zamzami N, et al. Molecular characterization of mitochondrial apoptosisinducing factor. Nature 1999; 397:441-6.

[28] Jiang ZF, Zhang B, Zhai ZH. Nuclear reassembly in vitro is independent of nucleosome/chromatin assembly. Science in China (Series C) 1998; 41:512-9.

[29] Lohka MJ, Masui Y. Formation in vitro of sperm pronuclei and mitotic chromosomes induced by amphibian cytoplasmic components. Science 1983; 220:719-21.

[30] Blobel G, Potter U R. Nuclei from Rat Liver: Isolation Method That Combines Purify with High Yield. Science 1966; 154:1662-5.

[31] Pedersen PL, Greenawalt JW, Reynafarje B, et al. Preparation and characterization of mitochondria and submitochondrial particles of rat liver and liver-derived tissues. Methods in Cell Biology 1978; 20: 411-81.

[32] Morell S, Follmann H, Haberlein I. Identification and localization of the first glutaredoxin in leaves of a higher plant. Febs Lett. 1995; 369 (2-3):149-452.

[33] Jiang ZF, Zhu S, Zhai ZH. Apoptosis in mouse liver nuclei induced in cell-free system from egg extracts of Xenopus laevis. Chinese Science Bulletin 1998; 43:49-413.

[34] Cohen GM, Sun XM, Snowdon RT, et al. Key morphological features of apoptosis may occur in the absence of internucleosomal DNA fragmentation. Biochem J 1992; 286:331-4.

[35] Cummings OW, King TC, Holden JA, et al. Purification and characterization of the potent endonuclease in extracts of bovine heart mitochondria. J Biol Chem 1987; 262:2005-15.

[36] Henkart PA, Grinstein S. Apoptosis: mitochondria resurrected? J Exp Med 1996; 183:1293-5.

[37] Li P, Nijhawan D, Budihardjo I, et al. Cytochrome c and dATP-dependent formation of Apaf-1/caspase9 complex initiates an apoptotic protease cascade. Cell 1997; 91:470-89.

[38] Luo X, Budihardjo I, Zou H, et al. Bid, a Bcl2 interacting protein, mediates cytochrome c release from mitochondria in response to activation of cell surface death receptors. Cell 1998; 94:481-90.

[39] Li HL, Zhu H, Xu CJ, et al. Cleavage of BID by caspase 8 mediates the mitochondrial damage in the Fas pathway of apoptosis. Cell 1998; 94:491-501.

[40] Mancini M, Nicholson DW, Roy S, et al. The caspase-3 precursor has a cytosolic and mitochondrial distributionn: implications for apoptotic signaling. J Cell Biol 1998; 140:1485-95.

[41] Zhao Y, Jiang ZF, Sun YL, et al. Apoptosis of mouse liver nuclei induced in the cytosol of carrot cells. Febs Lett 1999; 448(1):197-200.

[42] Cote J, Renaud J, Ruid-Carrillo A. Recognition of (dG)n.(dC)n sequences by endonuclease G. Characterization of the calf thymus nuclease. J Biol Chem 1989; 264:3301-10.

[43] Gerschenson M, Houmiel KL, Low RL. Endonuclease G from mammalian nuclei is identical to the major endonuclease of mitochondria. Nucleic Acids Res 1995; 23:88-97.

[44] Mao PL, Jiang YL, Wee BY, et al. Activation of caspase-1 in the nucleus requires nuclear translocation of pro-caspase-1 mediated by its prodomain. J Biol Chem 1998; 273:23621-24.

Received July-19-2000. Revised Aug-10-2000. Accepted Aug-15-2000. 